\title{
Rationale for stopping cervical screening in women over 50
}

\author{
W J Van Wijngaarden, I D Duncan
}

\begin{abstract}
Objective-To investigate whether the currently recommended age at which to stop cervical screening (64) can be lowered and what criteria should be used for safely doing so.

Design-Retrospective case analysis study.

Setting-Dundee and Angus districts of Scotland.

Subjects-Women diagnosed as having cervical intraepithelial neoplasia and microinvasive or invasive cancer of the cervix in 1989 and 1990 (798 cases).

Main outcome measure-History of cervical cytology results according to age (age groups of five years) and screening interval (three years and five years).

Results-Cervical intraepithelial neoplasia was most common in women under 45 (711 cases in women of $\mathbf{4 5}$ and under $v 38$ cases in those of $\mathbf{4 6}$ and over). Cervical intraepithelial neoplasia occurring de novo was not seen in women over 50 who had been screened every three years. Microinvasive or invasive cancer of the cervix was diagnosed in 26 women over 50. None of these women had participated adequately in the cervical screening programme.
\end{abstract}

Conclusion-Cervical intraepithelial neoplasia typically occurs in younger women. All women over 50 with an adequate history of negative results on smear testing every three years may be safely discharged from further screening if these findings are confirmed in other populations.

\section{Introduction}

The detection and treatment of premalignant conditions by cervical screening programmes reduces both the incidence of and mortality from invasive squamous cancer of the cervix. Cervical cytology screening programmes began haphazardly in Britain from the 1960s onwards. Different recommendations were made independently for Scotland, England, and Wales, ${ }^{1-3}$ and there were local variations from one health authority to another in the way that these were implemented. An intercollegiate working party was set up to look particularly at the clinical aspects of the cervical screening programmes and to make recommendations for the United Kingdom as a whole. It reported in November $1987 . .^{4}$ The fundamental difference recommended was a change from opportunistic screening to a computerised call and recall of women aged 20-64 years. Screening beyond the age of 64 was not considered necessary provided that such women had had three consecutive smear tests with negative results, the most recent one no more than three years previously. The rationale for this was the low incidence of preinvasive disease in older women such as those in Dundee and Angus.s

In 1989 and $1990,71 \%$ and $76 \%$ respectively of all the women aged between 20 and 59 in Tayside, Scotland, had been screened at least once within the previous five years. Women were excluded from screening for reasons such as hysterectomy (about $7 \%$ ), virginity, terminal disease, etc. The true coverage of cervical screening by the end of 1990 for the Tayside region was therefore estimated to be well over $80 \%$ of women between 20 and 60 . Table I shows the percentage of women in the region who were never screened. The districts of Dundee and Angus, part of Tayside region, have a total population of women between 16 and 59 of around 167000 (1991 census). From this population over 57000 smears were taken during the two years of our study.

TABLE I-Percentages of women in Tayside who had never had cervical smear test at each date

\begin{tabular}{lcccc}
\hline $\begin{array}{l}\text { Age } \\
\text { (years) }\end{array}$ & $\begin{array}{c}31 \text { December } \\
1987\end{array}$ & $\begin{array}{c}\text { 31 December } \\
1988\end{array}$ & $\begin{array}{c}\text { 31 December } \\
1989\end{array}$ & $\begin{array}{c}31 \text { December } \\
1990\end{array}$ \\
\hline $20-24$ & 49 & 44 & 35 & 37 \\
$25-29$ & 35 & 28 & 19 & 16 \\
$30-34$ & 31 & 24 & 16 & 12 \\
$35-39$ & 29 & 20 & 15 & 11 \\
$40-44$ & 26 & 19 & 14 & 11 \\
$45-49$ & 29 & 20 & 15 & 11 \\
$50-54$ & 32 & 22 & 17 & 13 \\
$55-59$ & 39 & 28 & 22 & 17 \\
$\geqslant 60$ & 68 & 65 & 62 & 57 \\
\hline
\end{tabular}

The cytopathology laboratory serving Dundee and Angus was among the first to complete computerised call of the local population. This gave us the opportunity to re-examine the incidence of cervical intraepithelial neoplasia to determine whether it might be feasible to stop screening at an earlier age. As well as having benefits, health screening also has disadvantages - for example, inducing needless anxiety in people who do not have the disease in question and no significant prospect of developing it. In addition, there is clearly a need to use health service resources as cost effectively as possible. Identifying a group of women who no longer benefit from cervical screening is therefore an attractive proposition.

\section{Subjects and methods}

Data on cervical cytology for women in the adjacent Scottish regions of Tayside, Fife, and Central are held on a mainframe computer system (OCCURS - on line cervical cytology update and recall system). Recall every five years has been the standard, but many general practitioners have offered a service every three years. There is one colposcopy clinic serving the women of Dundee and Angus, and the records of all cases of cervical intraepithelial neoplasia detected are entered on to a computer database. Similarly all cases of microinvasive and invasive cancer detected in Tayside are entered on to the database of the gynaecological cancer register.

All cases of cervical neoplasia detected between 1 January 1989 and 31 December 1990 in women of Dundee and Angus were analysed according to the patient's age group and correlated with their history of cervical cytology screening. The following five categories were defined for a screening interval of three years:

N3, no or inadequate history of smear tests-no smear or only one smear taken within eight years before the test leading to the diagnosis of cervical intraepithelial neoplasia (index smear) by colposcopically directed biopsy. 
I3, incident disease-two or more smear tests with negative results at three year intervals with the most recent having been at least two years before the index smear.

P3, prevalent disease - two or more smear tests at three year intervals with the most recent having been at least two years before the index smear and at least one of these tests having given abnormal results.

?I3, ?incident disease-cases not strictly fulfilling category $\mathrm{I} 3$ but on analysis seeming to be incident disease.

?P3, ?prevalent disease-those not strictly fulfilling category P3 but on analysis seeming to be prevalent disease.

Five similar categories were defined for a five year screening interval.

$\mathrm{N} 5$, no or inadequate history of smear tests-no smear or only one smear taken within 10 years before the index smear.

I5, incident disease-two or more smear tests with

TABLE II-Numbers of cases of cervical neoplasia and of smear tests by age group in women who lived in Dundee and Angus in 1989 and 1990

\begin{tabular}{|c|c|c|c|c|c|c|c|}
\hline \multirow{2}{*}{$\begin{array}{l}\text { Age } \\
\text { (years) }\end{array}$} & \multicolumn{3}{|c|}{ Cervical intraepithelial neoplasia } & \multirow{2}{*}{$\begin{array}{r}\text { Microinvasive } \\
\text { carcinoma }\end{array}$} & \multirow{2}{*}{$\begin{array}{l}\text { Squamous } \\
\text { carcinoma }\end{array}$} & \multirow[b]{2}{*}{ Adenocarcinoma } & \multirow[b]{2}{*}{ Smear test } \\
\hline & Grade I & Grade II & Grade III & & & & \\
\hline$<21$ & 16 & 25 & 25 & 0 & 0 & 0 & \\
\hline $21-25$ & 36 & 52 & 96 & 1 & 0 & 0 & 21927 \\
\hline $26-30$ & 25 & 40 & 136 & 2 & 0 & 1 & \\
\hline $31-35$ & 15 & 23 & 88 & 2 & 3 & 0 & 7300 \\
\hline $36-40$ & 7 & 20 & 45 & 1 & 2 & 2 & 6675 \\
\hline $41-45$ & 8 & 13 & 41 & 1 & 3 & 1 & 6410 \\
\hline $46-50$ & 7 & 7 & 8 & 1 & 0 & 3 & 4773 \\
\hline $51-55$ & 1 & 2 & 7 & 0 & 4 & 0 & 4427 \\
\hline $56-60$ & 0 & 2 & 3 & 1 & 4 & 0 & 3683 \\
\hline$>60$ & 0 & 1 & 0 & 1 & 12 & 4 & 2320 \\
\hline Total & 115 & 185 & 449 & 10 & 28 & 11 & 57515 \\
\hline
\end{tabular}

TABLE III-Numbers of smears taken for each case of cervical intraepithelial neoplasia detected by age group in women who lived in Dundee and Angus in 1989 and 1990

\begin{tabular}{lcccc}
\hline & \multicolumn{4}{c}{ Cervical intraepithelial neoplasia } \\
\cline { 2 - 5 } Age (years) & Grade I & Grade II & Grade III & All grades \\
\hline$<31$ & 285 & 187 & 85 & 49 \\
$31-35$ & 487 & 317 & 83 & 58 \\
$36-40$ & 954 & 334 & 148 & 93 \\
$41-45$ & 801 & 493 & 156 & 103 \\
$46-50$ & 682 & 682 & 597 & 217 \\
$51-55$ & 4427 & 2214 & 632 & 443 \\
$56-60$ & $\infty^{\star}$ & 1842 & 1228 & 737 \\
$>60$ & $\infty^{\star}$ & 3320 & $\infty^{\star}$ & 3320 \\
\hline \multirow{2}{*}{ Infinite number } & & & &
\end{tabular}

TABLE IV-Numbers of cases of cervical intraepithelial neoplasia detected in women who lived in Dundee and Angus in 1989 and 1990 analysed by age group and history of cytology screening at three and five year intervals

\begin{tabular}{|c|c|c|c|c|c|c|}
\hline \multirow[b]{2}{*}{ Details of cervical intraepithelial neoplasia } & \multicolumn{2}{|c|}{ Aged 41-45 } & \multicolumn{2}{|c|}{ Aged 46-50 } & \multicolumn{2}{|c|}{ Aged $>50$} \\
\hline & $\begin{array}{c}\text { Screened } \\
\text { every } \\
\text { three } \\
\text { years }\end{array}$ & $\begin{array}{c}\text { Screened } \\
\text { every } \\
\text { five } \\
\text { years }\end{array}$ & $\begin{array}{c}\text { Screened } \\
\text { every } \\
\text { three } \\
\text { years }\end{array}$ & $\begin{array}{l}\text { Screened } \\
\text { every } \\
\text { five } \\
\text { years }\end{array}$ & $\begin{array}{c}\text { Screened } \\
\text { every } \\
\text { three } \\
\text { years }\end{array}$ & $\begin{array}{c}\text { Screened } \\
\text { every } \\
\text { five } \\
\text { years }\end{array}$ \\
\hline \multicolumn{7}{|l|}{ Grade I: } \\
\hline Total & 8 & 8 & 7 & 7 & 1 & 1 \\
\hline No or inadequate history of smear tests & 5 & 6 & 3 & 4 & 1 & 1 \\
\hline Prevalent (?prevalent) disease & 0 & 0 & 1 & $1(1)$ & 0 & 0 \\
\hline Incident (?incident) disease & 3 & 2 & $2(1)$ & 1 & 0 & 0 \\
\hline \multicolumn{7}{|l|}{ Grade II: } \\
\hline Total & 13 & 13 & 7 & 7 & 5 & 5 \\
\hline No or inadequate history of smear tests & 11 & 10 & 5 & 2 & 5 & 5 \\
\hline Prevalent (?prevalent) disease & 2 & $1(1)$ & 1 & 1 & 0 & 0 \\
\hline Incident (?incident) disease & 0 & $0(1)$ & $0(1)$ & $2(2)$ & 0 & 0 \\
\hline \multicolumn{7}{|l|}{ Grade III: } \\
\hline Total & 41 & 41 & 8 & 8 & 10 & 10 \\
\hline No or inadequate history of smear tests & 37 & 27 & 6 & 5 & 9 & 6 \\
\hline Prevalent (?prevalent) disease & 2 & 2 & 2 & $1(1)$ & 1 & 1 \\
\hline Incident (?incident) disease & $1(1)$ & $7(5)$ & 0 & 1 & 0 & $1(2)$ \\
\hline \multicolumn{7}{|l|}{ All grades: } \\
\hline Total & 62 & 62 & 22 & 22 & 16 & 16 \\
\hline No or inadequate history of smear tests & 53 & 43 & 14 & 11 & 15 & 12 \\
\hline Prevalent (?prevalent) disease & 4 & $3(1)$ & 4 & $3(1)$ & 1 & 1 \\
\hline Incident (?incident) disease & $4(1)$ & $9(6)$ & $2(2)$ & $4(3)$ & 0 & $1(2)$ \\
\hline
\end{tabular}

negative results at four to five year intervals with the most recent at least three years before the index smear.

P5, prevalent disease-two or more smear tests at four to five year intervals with the most recent at least three years before the index smear and at least one of these having given abnormal results.

?5, incident disease-cases not strictly fulfilling category I5 but on analysis seeming to be incident disease.

?P5, prevalent disease-cases not strictly fulfilling category P5 but on analysis seeming to be prevalent disease.

The data were analysed with these various categories. The denominators were the numbers of smears taken between 1 January 1989 and 31 December 1990 in the corresponding age groups. We could not separate out women who had had more than one smear taken during this time. There would, however, have been few such women. Those with more than one smear taken would most likely have been followed up after treatment for cervical intraepithelial neoplasia and, according to protocol, would have had no more than three smears taken over the two year period. Most of these women (about $80 \%$ ) would have been younger than 35 . Very few women would have had more than two abnormal results as two borderline or mildly dyskaryotic results automatically qualify a women for colposcopy. These women would also have been mainly in the younger age groups. Our aim was to determine whether continuation of cervical screening is necessary in older women with a history of consistently negative results. Analysis of the data was concentrated on them and so we do not think that the results in the older age groups are invalidated by using numbers of smear tests as the denominator.

\section{Results}

Table II shows the number of women diagnosed as having cervical neoplasia in the two years of the study compared with the number of smears taken in the corresponding age groups. Similar numbers of smears were taken in women aged between 31 and 45 and in women aged up to 30 , but cervical intraepithelial neoplasia was much commoner in the younger group. Table III shows the number of smears taken per case detected. Grade III disease is more commonly diagnosed than grade II disease, which is more commonly diagnosed than grade I disease. The frequency with which cervical intraepithelial neoplasia grades II and III are detected declines with age whereas the decline in the detection of grade I disease is apparently arrested temporarily in the fifth decade. The decline in cervical intraepithelial neoplasia grade III is slower than the decline in grade II disease, which is slower than the decline in grade I disease. About $98 \%$ of all cases $(733$ of 749) were found in women aged 50 or younger. Figure 1 shows the number of cases detected for each 10000 smears taken.

In tables IV and $\mathrm{V}$ the data were further analysed for women over the age of 40 by comparing the number of cases of cervical intraepithelial neoplasia and microinvasive and invasive neoplasia detected according to the various categories of smear history. In women older than 50 cervical intraepithelial neoplasia grade I was detected only once. This 55 year old woman had had only two smears taken over 13 years and was therefore by our definitions inadequately screened. Five cases of cervical intraepithelial neoplasia grade II were detected in women aged 51 to 74 . Only one had ever had a smear taken, some 20 years previously. Ten cases of cervical intraepithelial neoplasia grade III were detected in women aged 51 to 59 . Three had had no smear tests and one had had only one smear test. Two women had had two smear tests over 12 and 17 years respectively, 


\begin{tabular}{|c|c|c|c|c|c|c|c|c|c|c|}
\hline \multirow[b]{2}{*}{ Cases } & \multicolumn{2}{|c|}{ Aged 41-45 } & \multicolumn{2}{|c|}{ Aged 46-50 } & \multicolumn{2}{|c|}{ Aged 51-55 } & \multicolumn{2}{|c|}{ Aged 56-60 } & \multicolumn{2}{|c|}{ Aged $>60$} \\
\hline & $\begin{array}{c}\text { Screened } \\
\text { every } \\
\text { three } \\
\text { years }\end{array}$ & $\begin{array}{l}\text { Screened } \\
\text { every } \\
\text { five } \\
\text { years }\end{array}$ & $\begin{array}{c}\text { Screened } \\
\text { every } \\
\text { three } \\
\text { years }\end{array}$ & $\begin{array}{l}\text { Screened } \\
\text { every } \\
\text { five } \\
\text { years }\end{array}$ & $\begin{array}{c}\text { Screened } \\
\text { every } \\
\text { three } \\
\text { years }\end{array}$ & $\begin{array}{l}\text { Screened } \\
\text { every } \\
\text { five } \\
\text { years }\end{array}$ & $\begin{array}{c}\text { Screened } \\
\text { every } \\
\text { three } \\
\text { years }\end{array}$ & $\begin{array}{l}\text { Screened } \\
\text { every } \\
\text { five } \\
\text { years }\end{array}$ & $\begin{array}{c}\text { Screened } \\
\text { every } \\
\text { three } \\
\text { years }\end{array}$ & $\begin{array}{l}\text { Screened } \\
\text { every } \\
\text { five } \\
\text { years }\end{array}$ \\
\hline Total & $5(1)^{\star}$ & $5(1)^{\star}$ & $4(3)^{\star}$ & $4(3)^{\star}$ & 4 & 4 & 5 & 5 & $17(4)^{\star}$ & $17(4)^{\star}$ \\
\hline No or inadequate history of smear tests & $5(1)^{\star}$ & 4 & $3(3)^{\star}$ & $4(3)^{\star}$ & 4 & 4 & 5 & 5 & $17(4)^{\star}$ & $17(4)^{\star}$ \\
\hline Prevalent (?prevalent) disease & 0 & 0 & 0 & 0 & 0 & 0 & 0 & 0 & 0 & 0 \\
\hline Incident (?incident) disease & 1 & $1(1)^{\star}$ & $0(1)$ & 0 & 0 & 0 & 0 & 0 & 0 & 0 \\
\hline
\end{tabular}

*No of cases of adenocarcinoma included in total.

TABLE VI-Numbers of smears taken for each case of cervical intraepithelial neoplasia detected in women who lived in Dundee and Angus in 1989 and 1990

\begin{tabular}{|c|c|c|c|c|c|c|c|c|c|c|}
\hline \multirow[b]{2}{*}{$\begin{array}{l}\text { Details of } \\
\text { cervical intraepithelial neoplasia }\end{array}$} & \multicolumn{2}{|c|}{ Aged 41-45 } & \multicolumn{2}{|c|}{ Aged 46-50 } & \multicolumn{2}{|c|}{ Aged 51-55 } & \multicolumn{2}{|c|}{ Aged 56-60 } & \multicolumn{2}{|c|}{ Aged $>60$} \\
\hline & $\begin{array}{c}\text { Screened } \\
\text { every } \\
\text { three } \\
\text { years }\end{array}$ & $\begin{array}{l}\text { Screened } \\
\text { every } \\
\text { five } \\
\text { years }\end{array}$ & $\begin{array}{l}\text { Screened } \\
\text { every } \\
\text { three } \\
\text { years }\end{array}$ & $\begin{array}{l}\text { Screened } \\
\text { every } \\
\text { five } \\
\text { years }\end{array}$ & $\begin{array}{l}\text { Screened } \\
\text { every } \\
\text { three } \\
\text { years }\end{array}$ & $\begin{array}{l}\text { Screened } \\
\text { every } \\
\text { five } \\
\text { years }\end{array}$ & $\begin{array}{l}\text { Screened } \\
\text { every } \\
\text { three } \\
\text { years }\end{array}$ & $\begin{array}{l}\text { Screened } \\
\text { every } \\
\text { five } \\
\text { years }\end{array}$ & $\begin{array}{c}\text { Screened } \\
\text { every } \\
\text { three } \\
\text { years }\end{array}$ & $\begin{array}{c}\text { Screened } \\
\text { every } \\
\text { five } \\
\text { years }\end{array}$ \\
\hline \multicolumn{11}{|l|}{ Grade I: } \\
\hline $\mathrm{I}+\mathrm{P}+\mathrm{P}+? \mathrm{P}+\mathrm{N}$ & 801 & 801 & 682 & 682 & 4427 & 4427 & $\infty^{\star}$ & $\infty^{\star}$ & $\infty^{\star}$ & $\infty^{\star}$ \\
\hline $\mathrm{I}+? \mathrm{I}+\mathrm{P}+? \mathrm{P}$ & 2137 & 3205 & 1193 & 1591 & $\infty^{\star}$ & $\infty^{\star}$ & $\infty^{\star}$ & $\infty^{\star}$ & $\infty^{\star}$ & $\infty^{\star}$ \\
\hline $\mathrm{I}+$ ? I & 2137 & 3205 & 1591 & 4773 & $\infty^{\star}$ & $\infty^{\star}$ & $\infty^{\star}$ & $\infty^{\star}$ & $\infty^{\star}$ & $\infty^{\star}$ \\
\hline \multicolumn{11}{|l|}{ Grade II: } \\
\hline $\mathrm{I}+? \mathrm{I}+\mathrm{P}+? \mathrm{P}+\mathrm{N}$ & 493 & 493 & 682 & 682 & 2214 & 2214 & 1842 & 1842 & 3320 & 3320 \\
\hline $\mathrm{I}+? \mathrm{I}+\mathrm{P}+? \mathrm{P}$ & 3205 & 2137 & 2387 & 955 & $\infty^{\star}$ & $\infty^{\star}$ & $\infty^{\star}$ & $\infty^{\star}$ & $\infty^{\star}$ & $\infty^{\star}$ \\
\hline $\mathrm{I}+$ ? I & $\infty^{\star}$ & 6410 & 4773 & 1193 & $\infty^{\star}$ & $\infty^{\star}$ & $\infty^{\star}$ & $\infty^{\star}$ & $\infty^{\star}$ & $\infty \infty^{\star}$ \\
\hline \multicolumn{11}{|l|}{ Grade III: } \\
\hline $\mathrm{I}+\mathrm{I}+\mathrm{P}+? \mathrm{P}+\mathrm{N}$ & 156 & 156 & 597 & 597 & 632 & 632 & 1228 & 1228 & $\infty^{\star}$ & $\infty^{\star}$ \\
\hline $\mathrm{I}+? \mathrm{I}+\mathrm{P}+? \mathrm{P}$ & 1603 & 458 & 2387 & 2387 & 4427 & 1476 & $\infty^{\star}$ & 3683 & $\infty^{\star}$ & $\infty^{\star}$ \\
\hline $\mathrm{I}+? \mathrm{I}$ & 3205 & 534 & $\infty$ & 4773 & $\infty^{\star}$ & 2214 & $\infty^{\star}$ & 3683 & $\infty^{\star}$ & $\infty^{\star}$ \\
\hline \multicolumn{11}{|l|}{ All grades: } \\
\hline $\mathrm{I}+? \mathrm{I}+\mathrm{P}+? \mathrm{P}+\mathrm{N}$ & 103 & 103 & 217 & 217 & 443 & 443 & 737 & 737 & 3320 & 3320 \\
\hline $\mathrm{I}+? \mathrm{I}+\mathrm{P}+? \mathrm{P}$ & 712 & 337 & 597 & 434 & 4427 & 1476 & $\infty^{\star}$ & 3683 & $\infty^{\star}$ & $\infty^{\star}$ \\
\hline $\mathrm{I}+? \mathrm{I}$ & 1282 & 427 & 1193 & 796 & $\infty^{\star}$ & 2214 & $\infty^{\star}$ & 3683 & $\infty^{\star}$ & $\infty^{\star}$ \\
\hline
\end{tabular}

$\mathrm{I}+? \mathrm{I}+\mathrm{P}+? \mathrm{P}+\mathrm{N}-$ all cases including those inadequately screened previously

$\mathrm{I}+? \mathrm{I}+\mathrm{P}+? \mathrm{P}-$ all cases excluding those inadequately screened previously.

$\mathrm{I}+$ ? I-all cases of incident and ?incident cervical intraepithelial neoplasia.

$\infty{ }^{\star}$-infinite number as no cases detected.

which again did not constitute adequate screening. Two others had had two smear tests in 11 years, which was categorised as inadequate history in the group defined by screening every three years but ?incident disease in the group defined by screening every five years according to our definitions. Similarly, one woman had had two smear tests in 10 years which was categorised as inadequate history in the group defined by screening every three years but as incident disease in the group defined by screening every five years. The last case was in a woman aged 52 who had had an abnormal result five years before diagnosis and had prevalent disease in the group defined by screening every three years but an inadequate history in the group defined by screening every five years.

Microinvasive and invasive squamous carcinoma was diagnosed four times in women aged 51 to 55 . One had had no previous smear tests. The others all fell into the category of inadequate history for both groups of screening interval as smears were taken 11 and 17, five and six, and two and 17 years respectively before detection. Five cases of microinvasive and invasive squamous carcinoma were detected in women aged 56 to 60 . Three had had no previous smear tests. The other two had had two smear tests at seven and 10 years and seven and 18 years respectively, which were categorised as inadequate histories for both groups of screening interval. Seventeen cases of microinvasive and invasive cervical carcinoma were detected in women aged 61 years and older. Four contained glandular elements. Fourteen had never had a smear test, and three had had only one taken 18 months (stage Ia squamous carcinoma), seven years (stage IIIb adenocarcinoma), and 17 years (stage Ib squamous carcinoma) respectively before diagnosis. These again were categorised as inadequate history.

No new cases of cervical intraepithelial neoplasia or of microinvasive or invasive carcinoma were found in

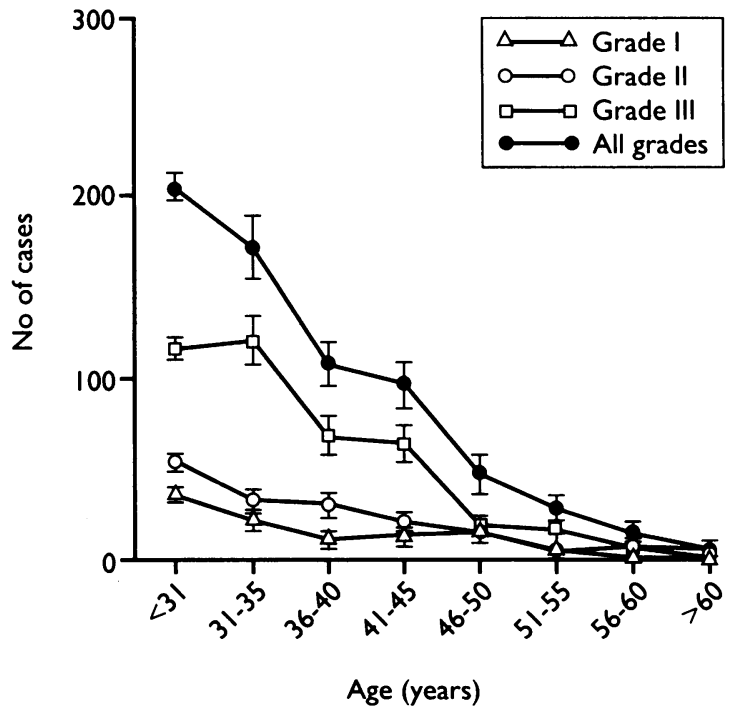

FIG 1-Numbers of cases of cervical intraepithelial neoplasia detected (with 1 SE) per 10000 smear tests in women who lived in Dundee and Angus in 1989 and 1990

women aged over 50 who had undergone screening every three years.

In table VI the number of smears taken for each case of cervical intraepithelial neoplasia diagnosed is analysed further in the older age groups according to their screening history. The number of smears taken for each case detected increases with age, with active participation in the cervical screening programme, and with a history of negative results; and the law of diminishing returns applies accordingly. This is graphically shown in figures 2 and 3, which give the number of cases of cervical intraepithelial neoplasia detected for each 10000 smears taken. 


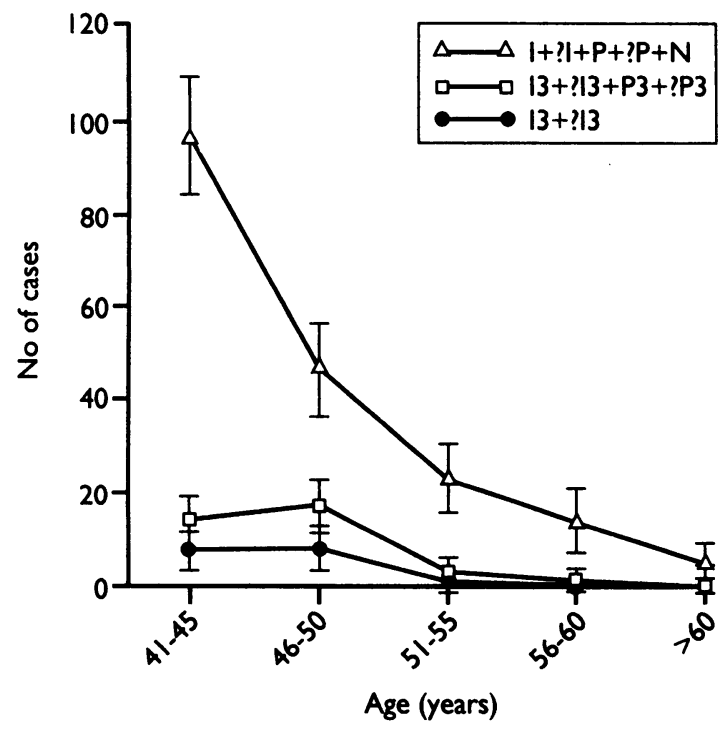

FIG 2-Incident and prevalent cervical intraepithelial neoplasia detected (with 1 SE) per 10000 smear tests in women who lived in Dundee and Angus in 1989 and 1990 showing effect of screening every five years. $I+? I+P+? P+N=$ all cases regardless of history of screening: $15+? 15+P 5+? P 5=$ all cases in women with history of screening every five years; $15+? 15=$ incident cases in women with history of screening every five years

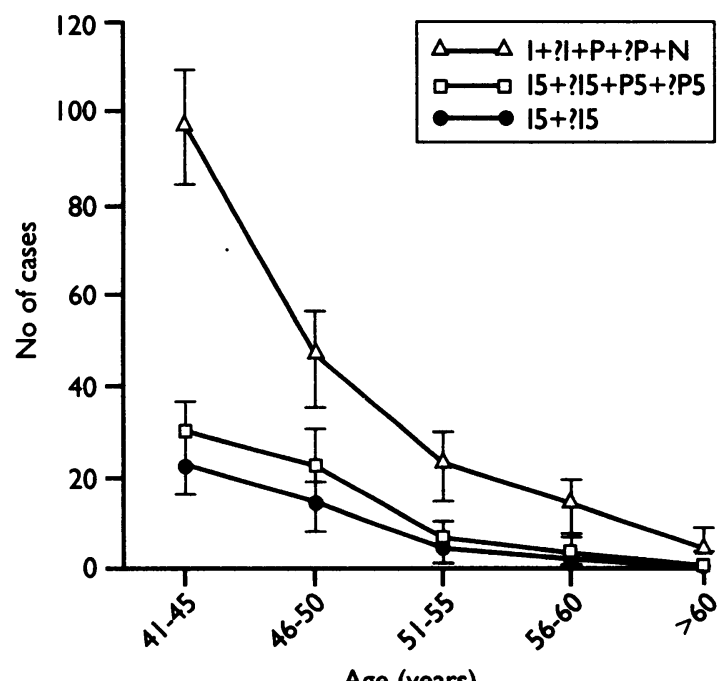

Age (years)

FIG 3-Incident and prevalent cervical intraepithelial neoplasia detected (with 1 SE) per 10000 smear tests in women who lived in Dundee and Angus in 1989 and 1990 showing effect of screening every three years. $I+? I+P+? P+N=$ all cases regardless of history of screening; $13+? 13+P 3+? P 3=$ all cases in women with history of screening every three years; $13+? 13=$ incident cases in women with history of screening every three years

\section{Discussion}

The guidelines for clinical practice and programme management published in 1992 by the national coordinating network of the National Health Service cervical screening programme advised that computerised call and recall for screening is not justified in women over 65. ${ }^{6}$ The recommendations contained in these guidelines were welcomed by every authoritative body concerned with cervical screening in the United Kingdom. Concern had been expressed that women over the age of 65 should not be ignored as a large proportion of the deaths from cervical cancer occur in women of this age ${ }^{7}$; in England and Wales in 1988 this proportion was $50 \%$ (965 of 1940). ${ }^{8}$ These women are unlikely to have participated in the cervical screening programme for a variety of reasons. In particular they were too old at the time to have derived benefit from opportunistic screening in antenatal and family planning clinics. This is recognised in the guidelines, which also recommend that such women should be encouraged to have a smear test if they are consulting a doctor and have not been screened previously.

The position is different for older women who have participated in the screening programme. Women over the age of 65 accounted for only $1.4 \%$ (108 of 7813) of new cases of carcinoma in situ of the cervix registered in England and Wales in 1984, ${ }^{9}$ and women over the age of 50 accounted for only $7 \cdot 8 \%$ (607 of 7813$)$. The generally accepted explanation for this is that most screening is carried out in younger women, who therefore account for most cases of premalignancy. ${ }^{9}$ Our data clearly show that this explanation is incomplete. By determining the number of smear tests carried out for each age group we have shown a distinct increase in the number of smears required to be taken for each case of cervical intraepithelial neoplasia detected with increasing age for all grades.

A prerequisite of any public health screening programme is that the condition sought must be reasonably common in the target population. A population subjected to screening should therefore be examined to determine those at low risk who stand to gain little from the screening process. Women living in Dundee and Angus have participated in a cervical screening programme since 1962. This programme has been associated with a considerable reduction in the incidence of and mortality from cervical cancer. ${ }^{5}$ We have long suspected that cervical intraepithelial neoplasia is a condition which develops predominantly in young women. Left undetected most cases probably regress spontaneously but some persist. Invasive cancer may develop after a variable period depending on various factors possibly involving a relaxation of immunocompetence. Persistent cervical intraepithelial neoplasia may be detected sooner or later depending on the frequency, adequacy, and correct interpretation of the smears taken. Our data show that it is extremely uncommon for cervical intraepithelial neoplasia to develop de novo in older women.

Once the existence of cervical intraepitheliai neoplasia can be confidently excluded the woman can be reassured and released from the screening programme. Currently this is the recommendation for women aged 64 provided that they have had three consecutive negative results, the most recent one no more than three years previously. Our data suggest that the age at which this applies could be lowered to 50 . In the Dundee and Angus laboratory this would have represented a saving of up to $18 \%$ (10 430 of 57515 ) of smear tests in 1989 and 1990. This resource could have been redistributed to increase the proportion of women screened every three rather than every five years or to allow more laboratory time for each smear test screened. Screening every five years has been calculated to improve reduction in the incidence of invasive cancer of the cervix from $83 \%$ to $91 \%,{ }^{10}$ and more laboratory time should reduce the chances of a test being falsely interpreted as negative. Our results would support such a preference for three yearly over five yearly screening. No new cases of premalignant disease of the cervix were seen in women over the age of 50 screened adequately every three years although there were a few in those who had been screened every five years.

So far the discussion has ignored any possible cohort effect. In brief, in England and Wales women born in the five years around 1921 have a higher mortality throughout their lives than previous birth cohorts this century. For subsequent birth cohorts the death rates are lower until that of 1941 . From the 1941 birth cohort onwards, the death rates have increased to reach a high for women born around 1951, whose risk of dying from cervical cancer is twice that of women born 10 years 
earlier, around 1941. A similar birth cohort effect is seen in incidence. ${ }^{8}$ There is little evidence for this particular effect in our study perhaps because Scottish women are less at risk than their English and Welsh contemporaries or perhaps because the risk can be largely negated by an effective screening programme.

Women reaching the age of 50 may welcome release from the cervical screening programme as they embark on the breast screening programme. It is not known whether the increasing uptake of hormone replacement therapy will maintain the higher incidence of cervical intraepithelial neoplasia seen in younger women by rejuvenating the cervix and a prospective randomised trial would be warranted.

We thank Dr K A Hussein in the cytopathology laboratory, Dundee Royal Infirmary, Margaret Bell in gynaecological cancer registry, Ninewells Hospital, Wilma Paterson in the Maryfield Computer Centre, and their colleagues for their close cooperation at all times.
1 Scottish Health Service Planning Council. Report on the cervical cytology service in Scotland by ad hoc group of the histopathology subcommittee of the scientific services advisory group. Scottish Home and Health Department, Edinburgh 1987.

2 Department of Health and Social Security. Health services management cervical cancer screening. London: Department of Health, 1988. (DHSSHC(88) cancer screening.

3 Health Service Division, Welsh Office. Cervical cytology screening services in Wales. Cardiff: National Health Service/Welsh Office Working Party, 1985.

4 Royal College of Obstetricians and Gynaecologists. Report of the intercollegiate working pary on cervical cytology screening. London: RCOG, 1987.

5 Duguid HLD, Duncan ID, Curry J. Screening for cervical intraepithelial neoplasia in Dundee and Angus 1962-1981 and its relationship with invasive cancer. Lancet 1985; ii:1053-6.

6 Duncan ID, ed. Guidelines for clinical practice and programme management. National co-ordinating network of the NHS cervical screening programme. Oxford: Oxford Regional Health Authority, 1992.

7 Fletcher A. Screening for cancer of the cervix in elderly women. Lancel 1990;335:97-9.

8 Cancer Research Campaign. Cancer of the cervix uteri. Oxford: Cancer Research Campaign, 1990. (Fact sheet 12.2.1990.)

9 Cancer Research Campaign. Cancer of the cervix uteri. Oxford: Cancer Research Campaign, 1990. (Fact Sheet 12.1.1990.)

10 International Association for Cancer Research Working Group on Valuation of Cervical Screening Programmes. Screening for squamous cervical cancer. Duration of low risk after negative cervical cytology and its implications for screening policies. BMF 1986;293:659-64.

(Accepted 4 February 1993)
University Department of Paediatrics, John Radcliffe Hospital, Oxford OX3 9DU Robert Booy, paediatric research fellow Sara Hodgson, paediatric research nurse E Richard Moxon, professor of paediatrics

\section{Department of Immunology} Helen Griffiths, clinical assistant in immunology Helen M Chapel, consultant immunologist

Correspondence to: Dr Booy.

BMF 1993;306:971-2

\section{Antibody persistence after accelerated immunisation against Haemophilus influenzae type b}

\author{
Robert Booy, Sara Hodgson, Helen Griffiths, \\ Helen M Chapel, E Richard Moxon
}

Haemophilus influenzae type $\mathrm{b}$ is a leading cause of bacterial meningitis in young children. As maternal antibodies decline infants become more susceptible to disease, and the peak incidence is at age 6-12 months.' Routine primary immunisation against $H$ influenzae type b was introduced in Britain in October 1992, with an accelerated schedule at 2,3 , and 4 months of age. A booster dose is not planned. Schedules for primary immunisation against $H$ influenzae type b in Europe and the United States are not completed until 5 or 6 months of age, and a booster dose is recommended in the second year of life.

We had previously immunised 107 infants according to the accelerated schedule with the conjugate vaccine polyribosylribitol phosphate-tetanus (PRP-T) (a polymer of ribosylribitol phosphate covalently linked to tetanus toxoid, Pasteur-Merieux) and established its immunogenicity. ${ }^{2}$ To determine if protective concentrations of antibody persist we followed up 95 infants until 1 year of age. The study was approved by the Central Oxford Research Ethics Committee.

\section{Patients, methods, and results}

The recruitment method was described previousiy. Polyribosylribitol phosphate-tetanus and diphtheriapertussis-tetanus immunisations were given separately by intramuscular injection at 2,3 , and 4 months. Venous blood was obtained for serological examination at 2 months, 5 months, and, in 95 infants, 1 year.

The concentration of total IgG antibody to polyribosylribitol phosphate was measured by enzyme linked immunosorbent assay (ELISA). ${ }^{2}$ Each sample taken at 1 year was assayed on the same plate as a previously collected sample from the same infant. The lower limit of sensitivity of the assay was $0.16 \mu \mathrm{g} / \mathrm{ml}$. Values below this were arbitrarily assigned the value $0.08 \mu \mathrm{g} / \mathrm{ml}$ for calculation of geometric mean titres.

At 1 year 89 infants had a serum polyribosylribitol phosphate antibody concentration $>0.15 \mu \mathrm{g} / \mathrm{ml}$ (figure). In 43 the concentration was $>1.0 \mu \mathrm{g} / \mathrm{ml}$. The geometric mean titre was $0.83 \mu \mathrm{g} / \mathrm{ml}$. Compared with

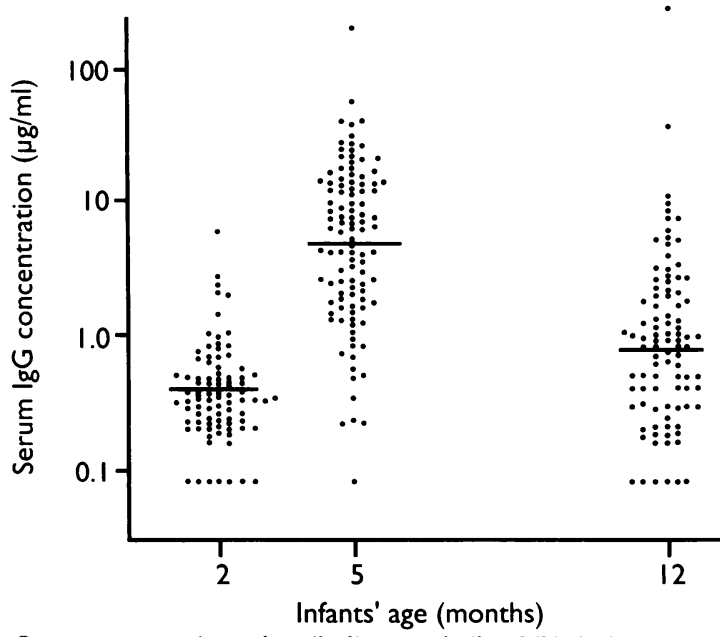

Serum concentrations of antibodies to polyribosylribitol phosphate in infants immunised at 2, 3, and 4 months (horizontal bars are geometric means)

the antibody concentrations measured at 5 months of age five infants showed at least a twofold rise and two of these showed more than fourfold rises at 1 year. None had clinical disease. One infant did not respond to primary immunisation (antibody concentration $<0.16 \mu \mathrm{g} / \mathrm{ml}$ at 5 months). A booster dose of the vaccine was given at 16 months, and one month later the antibody concentration was $3.4 \mu \mathrm{g} / \mathrm{ml}$.

\section{Comment}

We found that nearly all 1 year old infants immunised with polyribosylribitol phosphate-tetanus at 2,3 , and 4 months of age had serum antibody concentrations that are likely to be protective $(>0.15 \mu \mathrm{g} / \mathrm{ml})$. Without immunisation nearly all children of this age have antibody concentrations below $0 \cdot 15 \mu \mathrm{g} / \mathrm{ml}$ despite likely exposure to $H$ influenzae type b. ${ }^{3}$ The infant who failed to respond to primary immunisation was tested for immunodeficiency, but none was found and she responded well to a booster dose.

Immunisation of older infants-for example, according to the previous British schedule at ages 3, 5, and 9 months-produces higher antibody concentrations $^{3}$ and therefore prolongs protection if indeed prevention of disease depends on concentrations being maintained above a threshold. A booster in the second year of life is recommended in most countries with routine immunisation against $H$ influenzae type b. Our findings suggest that this may not be necessary. 